\title{
DISPARITIES OF REGIONAL HIGHER EDUCATION INSTITUTIONS IN LATVIA
}

Edmunds Jansons ${ }^{1}$, Ms.sc.comp.

${ }^{1}$ Latvia University of Life Sciences and Technologies

\begin{abstract}
The aim of the regional development is to promote and ensure balanced and sustainable development of the state. One of the approaches for ensuring equal development is related to the opportunities for acquiring tertiary education. The lack of diverse study programmes may cause risk of "brain drain" in-between the regions, as well as it may question the future sustainability of certain regions, thus causing negative long-term consequences for the regional development. Equal accessibility to higher education in the regions is an important preconditions for a balanced development of national economy. The analysis of data on the higher education institution enrolment, graduation and state funded study opportunities are analysed in order to determine the existing regional disparities between the statistical regions of Latvia and the higher education institutions (HEIs) within. The presented data show great disparities in terms of equal availability of graduates of certain fields of study among regions of which Vidzeme region stands out the with highest level of specialization among all RHEIs. The novelty of this study lies in the use of a study thematic fields based approach, thus further indicating the skills based disparities among the regions.
\end{abstract}

Key words: higher education, regional development, student distribution disparity. JEL code: D02, H52, I25.

\section{Introduction}

Higher education is a fundamentally important prerequisite for the creation of a functional knowledge society, while the purpose of the whole education system is to increase the competitiveness of each individual in the general labour market, while it can help to increase social cohesion. The cooperation efforts of the higher education institutions are tailored towards increasing the role of higher education in the integration of regional economic and convergence of every planning region (Knight, 2012; Sinkiene, Grumadaite, 2014; Grizane, Sannikova, Jasaitis, 2017).

In the regions of Latvia, socioeconomic disparities are significant due to the population of the state continuously centring around Riga planning region (especially the capital city), while in other regions the population is decreasing significantly (LR CSP, 2017). Similar situation can be observed also in the higher education system, i.e. the proportion of enrolled students in regions is decreasing while in the HEIs of Riga - increasing. In Latvia, the research on the overall role of regional HEIs (RHEI) in the regional perspective is not very common (Mazure, Viksne, 2007, 2008; Rivza, 2007, 2008; Brekis, 2015), while abroad this topic has been more deeply investigated.

Abroad the research of the RHEIs role has focused towards: (1) the RHEIs as a driving force of entrepreneurship, while increasing the prosperity in regions (Radinger-Peer, Pflitsch, 2017); (2) the HEIs in the commercialization of knowledge (Goldstein, Rehbogen, 2013); (3) the RHEI participation in the local and regional governance (Lawton-Smith, Bagchi-Sen, 2012; Goldstein, Glaser, 2013); (4) the involvement of RHEIs in the regional policy creation process (Trippl, Sinozic \& Lawton-Smith, 2015) and (5) the role of RHEIs for ensuring of regional sustainability (Goldstein, 2010). All of the mentioned themes are part of the goals defined in the 'Sustainable Development Strategy of Latvia until 2030' (Latvija 2030), hierarchically the highest national level long-term planning document, calling for the change of HE paradigm (PKC, 2012a). Further the 'National development plan 2014$2020^{\prime}$ (NAP) states the mid-term priorities in the field of education and science, while underlining actions for the fields of research, innovation, and tertiary education. The main tasks of the NAP include development of quality higher education according to the needs of the labour market, its

${ }^{1}$ E.Jansons - edmundjanson@gmail.com 
availability, competitiveness and consolidation (PKC, 2012b). The aim of the regional development, mentioned in the NAP2020, is to promote and ensure balanced and sustainable development of the state (PKC, 2012b). In the situation, when a disproportionate urban emigration of young people from regions to the capital takes place, it is necessary to analyse the statistical data on the students in the RHEIs of Latvia. In these settings the ISCED4 and ISCED 5 data can be considered as the main indicator for the highly educated part of the society Nonetheless the Masters and PhD degree can further the qualitative development of human capital (Mazure, Viksne, Rivza, 2018; Viksne, Mazure, 2007), while the ISCED 6 and ISCED 7 represent the further education trends. Thus the latter group may not be counted on top of the former group.

Aim of the research: to analyse the available statistical data on the regional state funded higher education institutions (HEIs), their enrolment, graduation and study opportunity indicators, thus determining the existing regional disparities between the statistical regions of Latvia and the HEIs within.

\section{Tasks of the research:}

1) to carry out analysis of disparities among the RHEIs of Latvia;

2) to investigate the student enrolment an graduation tendencies by their thematical field of studies in statistical regions of Latvia.

$$
H H I_{s}=\sum_{i=1}^{n}\left(\frac{x_{i}}{x}\right)_{s}^{2}
$$

Research methods: monographic method, descriptive statistics. In this research HerfindahlHirchman Index (HHI) index is applied. Although (HHI) is commonly used for market concentration measurements in a modified form it can also be used in regional economics. HHI index allows for two-dimensional comparison of the diversification within the given dataset (Kaivo-oja, Vahasantanen, et.al., 2017).The HHI formula is as follows:

where for $H H I_{y}$ the $x_{i}$ is the number of graduates of the specific study field (i) at a given RHEI and $(x)$ is the total number of graduates from all study fields in a HEI (s), and $(n)$ is the number of study fields. HHI-index is calculated as the sum of squared study field shares for each HEI. For $H H I_{X}$ the (i) is the number of HEIs, $(n)$ is the number of HEIs, while $x_{i}$ is the number of graduates of the specific HEI and $(x)$ is the total number of graduates from the specific field of studies. The index result Table is as follows: a HHI index below 0.01 indicates of a high diversification within the dataset, below 0.1 - an unconcentrated saturation, between 0.1 to 0.18 - indicates of a moderate concentration, above 0.18 - indicates of a high concentration (McCann,2001).

Research sources and materials: the research is based on documents, research papers of local and international origin, statistical data from the Ministry of Science and Education.

Research object: the research investigates the enrolment, graduation and study opportunities of (ISCED 4 to ISCED 7) students in the state established HEIs in the statistical regions of Latvia.

Research limitations: the research specifically focuses on the period from 2009 to 2017, which best describes the post financial crisis tendencies in the tertiary education. The analysis does not include data on state and legal person' established HEI' affiliates nor colleges in any of the statistical regions due to their different competitive role in the higher education system. 


\section{Research approach}

The meaning region, is defined as a marked territory based on geographical, economic and political traits (Baldunčiks, Pokrotniece, 2007). The term regional university is not defined in any of the regulations of the Republic of Latvia, thus author, taking into account the existing linguistic tendencies, state its meaning within this article as 'higher education institutions, which are placed outside of the capital'. In Latvia, a RHEI is considered a HEI which is located outside of the capital Riga (LV006). In the annual review on the "Higher education of Latvia 2017" six RHEIs can be identified: Latvia University of Life Sciences and Technologies (LLU); Daugavpils University (DU); Liepaja University (LiepU); Ventspils University College (VeA); Rezekne Academy of Technologies (RTA) and Vidzeme University of Applied Sciences (ViA) (IZM, 2018 ${ }^{\mathrm{a}}$ ). Which are located in four territorial units, Kurzeme (LV003), Latgale (LV005), Vidzeme (LV008), AND Zemgale (LV009) (CSB, 2015). The research includes analysis of data on student enrolment and graduation, as well as the availability of state funded study places on the basic (latv. - 'pamatstudijas') and higher (latv. 'augstaka limena studijas') level study thematic fields in six RHEIs. The research is based on publicly accessible information from the Ministry of Education and Science of Latvia (IZM) - annual statistics yearbook "Overview of the higher education" over the period from 2009 to 2017 (IZM, 2018 a). The statistics include summary indicators for the part-time and full-time students of two separate groups - ISCED (International Standard Classification of Education) $5^{\text {th }}$ and $6^{\text {th }}$ level as well as ISCED $7^{\text {th }}$ and $8^{\text {th }}$ level. The analysed period includes academic year 2009./2010 till 2017./2018. The higher education study programmes' $4^{\text {th }}$ classification level, considers eight study thematic fields (code in brackets) which include: Education, Humanities and Arts, Social Science and Commerce, Nature science, mathematics and IT, Engineering, production, construction, Agriculture, Health Science and Welfare, Services (MK, 2017).

\section{Research results and discussion}

The results of the analyses show that the proportion RHEIs versus the total number of HEIs (17 public and 16 legal person established institutions) in the country is $22 \%$. In 2017 just 3775 students enrolled in RHEIs, i.e. $19.5 \%$ of the total number (19350) of students enrolled in public HEIs, or just $15.6 \%$ of the total number (24141) of students enrolled in both public and private HEIs (IZM, $\left.2018^{\mathrm{a}}\right)$.

The enrolment data (Table 1 ) shows that the majority of students have enrolled in LLU (1346) and DU (853), while the least in VeA (264) and ViA (254). The overall analysis of the proportion of students choosing studies in any given field, show the most popular are Social science, commerce, law field related studies $(22.0 \%)$ and those of Engineering, production and construction field $(21.5 \%)$ which have reached parity. Meanwhile the least desirable choice for studies is in the Health and social welfare field $(2.9 \%)$.

It can be observed (Table 2) that during the research period among different thematic fields of study the overall numbers of ISCED 5 and ISCED 6 graduate students differ substantially. When comparing the top study fields by the number of graduates in the comprehensive field, the Social science, commerce and law field (7198 graduates) is the largest with the LLU at the front position (2844 graduates), followed by the Education field (3212 graduates) with DU at the forefront (1211 graduates) and Engineering field (3209 graduates) with LLU (2720 graduates) at the front. When ranking the universities by their total corresponding number of graduates in the given period, it is noticeable that the largest is LLU (7592 students), followed by DU (3920), LiepU (3189), RTA (2796), 
ViA (1653) and VeA (1180). When comparing the ISCED 4, ISCED 5 level data region-wise it can be seen that on most of students have graduated in Zemgale region (7592), followed by the Latgale region (6716), Kurzeme region (4369), and the Vidzeme region (1653).

Table 1

RHEI enrollment in tertiary education ISCED 5 to ISCED 8 in 2017/2018 in comparison to the total number of enrolled students in RHEIs (\%)

\begin{tabular}{|c|c|c|c|c|c|c|c|c|c|}
\hline HEI & 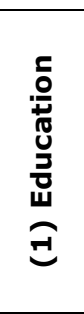 & 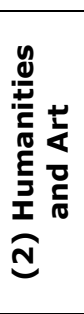 & 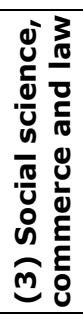 & 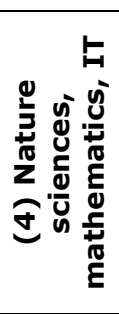 & 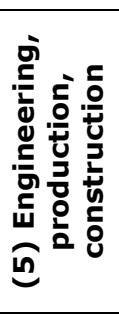 & $\begin{array}{l}0 \\
\frac{0}{3} \\
\frac{1}{3} \\
\frac{0}{2} \\
\frac{0}{4} \\
0 \\
0\end{array}$ & 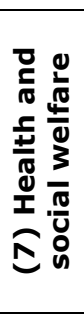 & 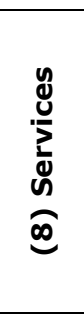 & $\begin{array}{c}\text { Total } \\
\text { number of } \\
\text { enrolled } \\
\text { students } \\
\text { per HEI }\end{array}$ \\
\hline LLU & 4.7 & - & 18.1 & - & 44.4 & 25.7 & 0.7 & 6.4 & 1346 \\
\hline DU & 24.7 & 28.6 & 16.1 & 15.9 & - & - & 4.6 & 10.1 & 853 \\
\hline LiepU & 32.4 & 18.9 & 14.6 & 16.9 & 1.1 & - & 9.3 & 6.8 & 472 \\
\hline RTA & 18.3 & 3.9 & 36 & 11 & 24.2 & - & 2.5 & 4.1 & 591 \\
\hline ViA & - & - & 25.6 & 34.3 & 20.1 & - & - & 20.1 & 254 \\
\hline VeA & - & 26.5 & 39.4 & 27.7 & 6.4 & - & - & - & 264 \\
\hline $\begin{array}{l}\text { Total number of } \\
\text { enrolled students } \\
\text { per field }\end{array}$ & 535 & 426 & 832 & 441 & 813 & 346 & 108 & 279 & 3780 \\
\hline$(\%)$ & 14.2 & 11.3 & 22.0 & 11.7 & 21.5 & 9.2 & 2.9 & 7.4 & 100 \\
\hline
\end{tabular}

Source: author's calculations based on (IZM, 2018 $)$

Table 2

Total number of ISCED 5 and ISCED 6 tertiary level graduates over the period from academic year $2009 / 2010$ until $2017 / 2018$ by RHEI and statistical regions

\begin{tabular}{|c|c|c|c|c|c|c|c|c|c|c|c|}
\hline 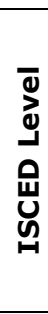 & $\begin{array}{l}\text { RHEI } \\
\text { and/or } \\
\text { region }\end{array}$ & 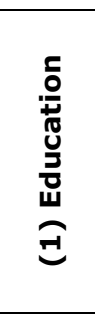 & 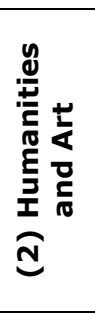 & 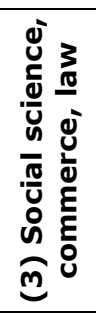 & 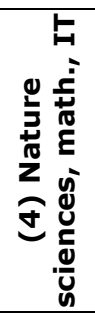 & 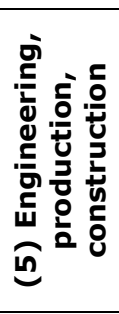 & $\begin{array}{l}0 \\
\frac{0}{3} \\
\frac{3}{3} \\
\frac{0}{2} \\
\frac{0}{4} \\
0\end{array}$ & 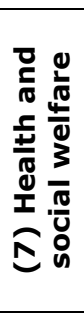 & 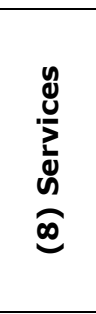 & 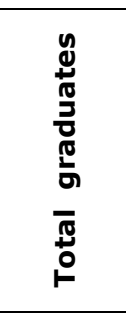 & 烏 \\
\hline \multirow{12}{*}{ 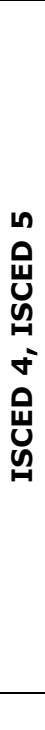 } & $\begin{array}{c}\text { LLU } \\
\text { (Total in } \\
\text { Zemgale) }\end{array}$ & 272 & - & 2844 & 64 & 2720 & 1379 & - & 313 & 7592 & 0.30 \\
\hline & DU & 1211 & 915 & 914 & 409 & - & - & 199 & 272 & 3920 & 0.22 \\
\hline & LiepU & 1152 & 404 & 874 & 145 & 3 & - & 330 & 281 & 3189 & 0.24 \\
\hline & RTA & 577 & 305 & 1220 & 111 & 304 & - & 51 & 228 & 2796 & 0.26 \\
\hline & $\begin{array}{c}\mathrm{ViA} \\
\text { (Total in } \\
\text { Vidzeme) }\end{array}$ & - & - & 905 & 360 & 101 & - & - & 287 & 1653 & 0.38 \\
\hline & VeA & - & 443 & 441 & 215 & 81 & - & - & - & 1180 & 0.31 \\
\hline & Region & \multicolumn{9}{|c|}{ (including Zemgale and Vidzeme region) } & $\bar{x}=0.29$ \\
\hline & Kurzeme & 1152 & 847 & 1315 & 360 & 84 & - & 330 & 281 & 4369 & 0.21 \\
\hline & Latgale & 1788 & 1220 & 2134 & 520 & 304 & - & 250 & 500 & 6716 & 0.22 \\
\hline & Subtotal: & 3212 & 2067 & 7198 & 1304 & 3209 & 1379 & 580 & 1381 & 20330 & $\bar{x}=0.26$ \\
\hline & $(\%)$ & 15.8 & 10.2 & 35.4 & 6.4 & 15.8 & 6.8 & 2.9 & 6.8 & 100 & \\
\hline & $H H I_{x}$ & 0.45 & 0.52 & 0.29 & 0.31 & 0.73 & 1.00 & 0.51 & 0.27 & $\overline{\bar{x}}=0.48$ & \\
\hline
\end{tabular}

Source: author's calculations based on (IZM, $\left.2018^{b}\right)$

On a more detailed level, in Kurzeme region the three largest groups of graduates are in Social science, commerce and law field (1315), Education field (1152) and Humanities and Art field (847). 
In Zemgale region -Social science, commerce and law field (2844), Engineering field (2720) and Agriculture (1379). In Latgale region -Social science, commerce and law field (1305), Education field (1029) and Humanities and Art (447). In Vidzeme region -Social science, commerce and law field (905), Nature sciences, math., IT (360) and Services (287). In the field of higher tertiary education level (ISCED 6 and ISCED 7), a similar situation can be observed. While the leader universities are different, the top study thematic fields are: Social science, commerce and law field with the DU at the front (868 graduates), followed by the Education field with DU (582 graduates) and Humanities and Art with the DU (406 graduates) in the leader positions.

Table 3

\section{Total number of ISCED 7 and ISCED 8 tertiary level graduates over the period from academic year 2009/2010 until $2017 / 2018$ by RHEI and statistical regions}

\begin{tabular}{|c|c|c|c|c|c|c|c|c|c|c|c|}
\hline 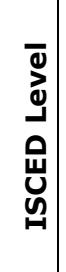 & $\begin{array}{l}\text { RHEI and/or } \\
\text { region }\end{array}$ & 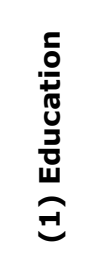 & 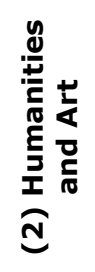 & 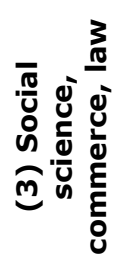 & 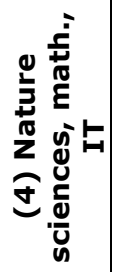 & 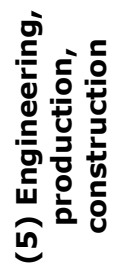 & $\begin{array}{l}\frac{0}{1} \\
\frac{1}{3} \\
\frac{0}{3} \\
\frac{0}{2} \\
\frac{0}{4} \\
0\end{array}$ & 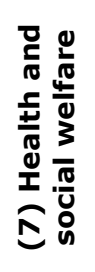 & 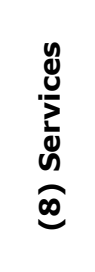 & 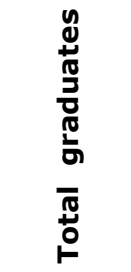 & 产 \\
\hline \multirow{15}{*}{ 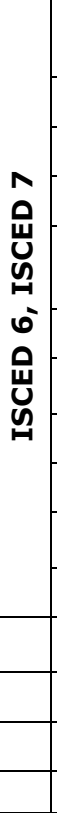 } & $\begin{array}{c}\text { LLU } \\
\text { (in Zemgale) } \\
\end{array}$ & 267 & - & 832 & 37 & 631 & 471 & 60 & 248 & 2546 & 0.22 \\
\hline & DU & 582 & 406 & 868 & 241 & - & - & 30 & 215 & 2342 & 0.25 \\
\hline & LiepU & 519 & 155 & 195 & 47 & - & - & 185 & 36 & 1137 & 0.29 \\
\hline & RTA & 447 & 41 & 437 & 111 & 29 & 0 & 0 & 114 & 1179 & 0.30 \\
\hline & $\begin{array}{c}\mathrm{ViA} \\
\text { (in Vidzeme) }\end{array}$ & - & 34 & 171 & 109 & - & - & - & 68 & 382 & 0.32 \\
\hline & VeA & - & 166 & 175 & 58 & 29 & - & - & - & 428 & 0.34 \\
\hline & Region & \multicolumn{9}{|c|}{ (including Zemgale and Vidzeme region) } & $\bar{x}=0.29$ \\
\hline & Kurzeme & 519 & 321 & 370 & 105 & 29 & - & 185 & 36 & 1565 & 0.23 \\
\hline & Latgale & 1029 & 447 & 1305 & 352 & 29 & - & 30 & 329 & 3521 & 0.26 \\
\hline & Subtotal: & 1815 & 802 & 2678 & 603 & 689 & 471 & 275 & 681 & 8014 & $\bar{x}=0.24$ \\
\hline & $(\%)$ & 22.6 & 10.0 & 33.4 & 7.5 & 8.6 & 5.9 & 3.4 & 8.5 & 100 & \\
\hline & $H H I_{X}$ & 0.42 & 0.47 & 0.36 & 0.41 & 0.84 & 1.00 & 0.51 & 0.38 & $\bar{x}=0.45$ & \\
\hline & Total: & 5027 & 2869 & 9876 & 1907 & 3898 & 1850 & 855 & 2062 & 28344 & \\
\hline & $(\%)$ & 17.7 & 10.1 & 34.8 & 6.7 & 13.8 & 6.5 & 3.0 & 7.3 & 100 & \\
\hline & $H H I_{x}$ & 0.44 & 0.50 & 0.30 & 0.33 & 0.75 & 1.00 & 0.47 & 0.29 & $\bar{x}=0.46$ & \\
\hline
\end{tabular}

Source: author's calculations based on (IZM, 2018 $\left.{ }^{b}\right)$

Ranking of the universities by their total corresponding number of ISCED 6 and ISCED7 graduates output (Table 3 ) reveals that most of students have graduated in Latgale region (3521), Zemgale region (2546) and Kurzeme region (1565) followed by Vidzeme region (382 graduates).

On a more detailed level, in Kurzeme region the three largest groups by thematic fields are of graduates in Education field (519) Social science, commerce and law field (370), and Humanities and Art field (321). In Zemgale region - Social science, commerce and law field (832), Engineering field (631) and Agriculture (471). In Latgale region - Social science, commerce and law field (1305), Education field (1029) and Humanities and Art (447). In Vidzeme region -Social science, commerce and law field (171), Nature sciences, math., IT (109) and Services (68).

When comparing the diversification of number of graduates within RHEIs according to the Herfindahl-Hirchman Index (HHI), due to the specificity of the research object, the HHI index Table can not be applied, since every $\mathrm{HHI}$ result is larger than 0.18 . Therefore a decision was made 
to separate the calculated results by a median. It can be seen, that on the ISCED 5 and ISCED 6 level (Table 2) on a HEI perspective $\left(\mathrm{HHI}_{\mathrm{y}}\right)$ the ViA (0.38), VeA (0.32) and LLU (0.30) have a slightly higher level of specialization levels than median (0.29) within certain fields of studies. On a regional level the highest HHI index has the Vidzeme region (0.38) and Zemgale (0.30) at $\bar{x}=0.26$ which indicates of an elevated level of specialization in certain fields of study. When evaluating among the study fields $\left(\mathrm{HHI}_{\mathrm{x}}\right)$, the highest level of $\mathrm{HHI}$ was observed in Agriculture (1.00); Engineering, production, construction (0.73); Humanities and Art (0.52); followed by Health and social welfare (0.51) at $\bar{x}=0.48$, thus indicating of somewhat limited opportunities to prepare the needed professionals within all regions. On the ISCED 7 and ISCED 8 level (Table 3 ) on a HEI perspective $\left(\mathrm{HHI}_{\mathrm{y}}\right) \mathrm{VeA}(0.34), \mathrm{ViA}(0.32)$ and RTA $(0.30)$ have an elevated diversification level at $\bar{x}=0.29$ within certain fields of studies. On a regional level the highest HHI index belongs to the Vidzeme region (0.32) and Latgale (0.26) at $\bar{x}=0.24$ which indicates of an elevated level of specialization in certain fields of study. When evaluating among the study fields $\left(\mathrm{HHI}_{\mathrm{x}}\right)$, the highest level of $\mathrm{HHI}$ was observed in Agriculture (1.00), Engineering, production, construction (0.84), followed by Health and social welfare (0.51) and Humanities and Art (0.47) at $\bar{x}=0.45$ indicating of somewhat limited opportunities to prepare the needed professionals within the given region.

Table 4

State funded ISCED 4,5,6 7 study places in RHEIs from 2009/2010 until $2017 / 2018$ ( \%)

\begin{tabular}{|c|c|c|c|c|c|c|c|c|c|}
\hline HEI & 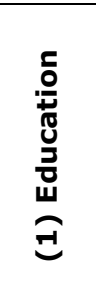 & 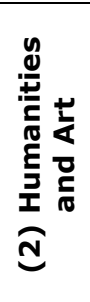 & 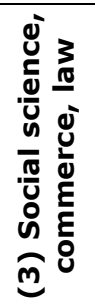 & 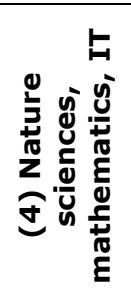 & 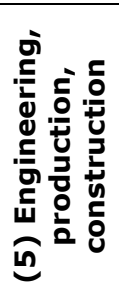 & $\begin{array}{l}\frac{0}{5} \\
\frac{1}{3} \\
\frac{0}{2} \\
\frac{5}{4} \\
0\end{array}$ & 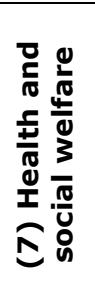 & $\begin{array}{l}y \\
\frac{u}{2} \\
\frac{2}{d} \\
\tilde{d} \\
\infty \\
\infty\end{array}$ & 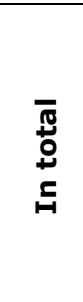 \\
\hline LLU (total Zemgale reg. ) & 45.2 & - & 40.6 & 82.2 & 77.5 & 61.4 & 96.7 & 57.1 & 70.7 \\
\hline DU & 64.5 & 84.8 & 46.0 & 95.4 & - & - & 53.5 & 67.4 & 61.6 \\
\hline LiepU & 63.2 & 76.5 & 28.0 & 86.2 & 100.0 & - & 59.9 & 72.2 & 62.4 \\
\hline RTA & 72.3 & 88.1 & 62.3 & 95.1 & 79.2 & - & 62.6 & 73.4 & 73.8 \\
\hline ViA (total Vidzeme reg.) & - & 81.8 & 51.8 & 83.8 & 83.7 & - & - & 67.9 & 80.8 \\
\hline VeA & - & 74.7 & 70.7 & 94.3 & 97.3 & - & - & - & 67.8 \\
\hline \multicolumn{10}{|l|}{ Region } \\
\hline Total in Kurzeme reg. & 63.2 & 75.6 & 47.8 & 90.5 & 97.6 & - & 59.9 & 72.2 & 63.2 \\
\hline Total in Latgale reg. & 67.6 & 85.4 & 54.1 & 95.3 & 79.2 & - & 55.5 & 69.2 & 71.9 \\
\hline $\begin{array}{l}\text { State funded study places in } \\
\text { total per study field ( \%) }\end{array}$ & 63.6 & 81.7 & 48.1 & 90.5 & 78.9 & 61.4 & 61.6 & 66.2 & 67.4 \\
\hline $\begin{array}{l}\text { State funded study places in } \\
2017 / 2018(\%)\end{array}$ & 59.1 & 92.0 & 59.7 & 85.0 & 83.3 & 65.6 & 65.7 & 72.4 & 72.9 \\
\hline
\end{tabular}

Source: author's calculations based on (IZM, 2018 $)$

The analysis of the situation according to the state funded study places (Table 4) shows that the financial availability of studies differs widely among the HEIs, regions and fields of study. The largest quantity of state funded study places were available in Vidzeme region, i.e. ViA (80.8\%), while the least in Kurzeme region (63.2 \%). On a regional level, the most subsidized field of studies were Nature sciences, mathematics, IT (90.5\%) and Humanities and Art (81.7\%), while the least - Social science, commerce and law (48.1\%). Overall an increase of financial support can be seen in every study field in 2017/2018 except for the Nature sciences, mathematics and IT field which saw a drop from $90.5 \%$ to $85.0 \%$. 
Data indicates that over the period from 2009/2010 until 2017/2018 in the most supported field - Nature sciences, mathematics - the percentage of enrolments was $11.7 \%$, the graduates' percentage was $13.8 \%$, while the financial support in 2017/2018 was reduced to $85 \%$. In Humanities and arts the percentage of enrolments was $11.3 \%$, the graduates percentage was $10.1 \%$, while the financial support in 2017/2018 was increased to $92 \%$. In the meantime, in the Social science, commerce and law field the percentage of enrolments was $22.0 \%$, the graduates percentage was $34.8 \%$, while in 2017/2018 the financial support was increased to $59.7 \%$. The significant differences in terms of both total quantity of graduate students and the diversity of study thematic fields (on both study level groups) between the leader region (Zemgale) and the lager region (Vidzeme) may have long-term implications for a sustainable regional growth thus questioning the role of government, regional planning bodies and the local municipalities in this process.

\section{Conclusions, proposals, recommendations}

1) Financial support to students of RHEIs in form of state funded study places has been disproportionate - the largest quantity has gone to Vidzeme region i.e. ViA ( $80.8 \%)$, while the least to DU (61.6\%). On a regional level, the most subsidized field of studies were Nature sciences, mathematics, IT (90.5\%) and Humanities and Art (81.7\%), while the least - Social science, commerce and law (48.1\%) which still has had the largest quantity of (7198 graduates).

2) In terms of the total number of ISCED 5 and ISCED 6 tertiary level graduates, in Kurzeme region the largest quantity of graduates is in Social science, commerce and law (1315), Education (1152) and Humanities and Art (847). In Zemgale region - Social science, commerce and law (2844), Engineering (2720) and Agriculture (1379). In Latgale region - Social science, commerce and law (1305), Education (1029), Humanities and Art (447). In Vidzeme region - Social science, commerce and law (905), Nature sciences, math., IT (360) and Services (287).

3 ) In terms of the total number of (ISCED $7 \& 8$ ) graduates, in Kurzeme region the three largest groups by thematic fields constitute of graduates in Education field (519) Social science, commerce and law field (370), Humanities and Art field (321). In Zemgale region - Social science, commerce and law field (832), Engineering field (631) and Agriculture field (471). In Latgale region - Social science, commerce and law field (1305), Education field (1029) and Humanities and Art (447). In Vidzeme region - Social science, commerce and law field (171), Nature sciences, math., IT (109) and Services (68).

4) The Herfindahl-Hirchman Index (HHI) diversification of graduates within RHEIs indicates that on ISCED 5 and ISCED 6 level the Vidzeme (0.38) and Zemgale (0.30) regions are specializing in certain fields of study. In terms of graduates of certain fields Agriculture (1.00); Engineering, production, construction (0.73); Humanities and Art (0.52); followed by Health and social welfare (0.51) graduates are least equally disseminated among regions. Similarly on ISCED 7 and ISCED 8 level the leaders in specialization are Vidzeme $(0.32)$ and Latgale $(0.26)$ regions while graduates of Agriculture (1.00), Engineering, production, construction (0.84), followed by Health and social welfare (0.51) and Humanities and Art (0.47) fields are least equally disseminated among regions of Latvia.

5) Further research is needed on the availability of study programmes within certain disciplines of higher education in the regions of Latvia as well as in terms of specialization of certain RHEIs and their harmonization with the long-term needs of the region. The presented data shows great disparities in terms of equal availability of graduates of certain fields of study in regions among 
which Vidzeme region stands out the with highest level of specialization among all RHEIs. Thus the ability to reach the long-term goals set by the government, regional planning bodies and the local municipalities in terms of tertiary education and regional development of Latvia should be further examined.

\section{Bibliography}

1. Baldunciks, J., Pokrotniece, K. (2007). Svesvardu vardnīca. Riga: Jumava, 931 lpp.

2. Brekis, E., Vilerts, K., Krasnopjorovs, O. (2015). Izglitibas ietekme uz algam Latvija ekonomiskas krizes laika un peckrizes perioda (2006.-2012. gada datu vertejums), Riga: Latvijas banka, p.51.

3. CSB (2015). Par statistiskajiem regioniem. Retrieved: http://www.csb.gov.lv/dokumenti/parstatistiskajiem-regioniem-28607.html. Access: 05.01.2019.

4. Goldstein, H. (2010). The 'Entrepreneurial Turn' and Regional Economic Development. Mission of Universities. Annals of Regional Science, Vol. 44(1), pp.83-109.

5. Goldstein, H., Glaser, K. (2012). Research Universities as Actors in the Governance of Local and Regional Development, Journal of Technology Transfer, Vol. 37 (2), Abstract, pp. 158-174.

6. Goldstein, H., Rehbogen, A. (2013). University Engagement and Knowledge Commercialization: an Analysis of Faculty Attitudes, Knowledge Commercialization and Valorization in Regional Economic Development., pp. 61-84.

7. Grizane, T. Sannikova, A., Jasaitis, J. (2017). Impact of Regional Higher Education Institutions on the Convergence of Regions. pp.44-52. Retrieved: http://www.esaf.Ilu.Iv/sites/esaf/files/files/lapas/Krajums_Nr_44_04092017.pdf. Access: 05.01.2019.

8. IZM (2018a). Parskats par Latvijas augstako izglitibu 2017.gada. Galvenie statistikas dati. Retrieved: https://www.izm.gov.Iv/images/zinatne/Prskats-par-Latvijas-augstko-izgltbu-2017.gad_2.pdf. Access: 03.01.2019.

9. IZM (2018b). Statistika par augstāko izglïtību. Galvenie statistikas dati. Retrieved: http https://www.izm.gov.Iv/lv/publikacijas-un-statistika/statistika-par-izglitibu/statistika-par-augstako-izglitibu Access: 03.01.2019.

10. Kaivo-oja S., Vahasantanen S. (2017) Smart specialization strategy and its operationalization in the regional policy: case Finland. Business, Management and Education ISSN 2029-7491, 2017, 15(1): 28-41. Retrieved: https://journals.vgtu.It/index.php/BME/article/download/391/274

11. Knight, J. (2012). A Conceptual Framework for the Regionalization of Higher Education: Application to Asia, in Higher Education Regionalization in Asia Pacific. Implications for Governance, Citizenship and University Transformation, (ed.) John N. Hawkins, Ka Ho Mok, Deane E. Neubauer. London: Palgrave Macmillan, p. 215.

12. Lawton-Smith, H., Bagchi-Sen, S. (2012). The Research University, entrepreneurship and regional development: Research propositions and current evidence. Entrepreneurship \& Regional Development, Vol. 24 (5-6), pp. 383-404.

13. LR CSP (Latvijas republikas centralas statistikas parvalde) (2017). ISG01. Pastavīgo iedzivotaju skaits regionos gada sakuma. Retrieved: http://data.csb.gov.Iv/pxweb/lv/Sociala/Sociala_ikgad_iedz_iedzskaits/IS0010.px/table/tableViewLayout 2/?rxid=cd. Access: 04.10.2018.

14. Mazure, G., Viksne, D., Rivza, B. (2008). Contribution of Higher education Institutions to Regional Development of Latvia. Proceedings of the 2nd International Conference on Educational Economics, (ICEE 2008), Greece: Athens, Fakulty of Economics at the National and Kapodistrian Universuty of Athens, p.17.

15. McCann, p. (2001): Urban and Regional Economics. Oxford University Press.

16. MK (2017) Cabinet of Ministers rules, No 322 on Clasification of Education of Latvia. Accepted in 13.06.2018.

17. PKC (Parresoru koordinacijas centrs) (2012a). POLSIS (Politikas planosanas dokumentu datubaze) Latvijas ilgtspejigas attistibas strategijas lïdz 2030.gadam istenosanas uzraudzibas zinojums. Retrieved: http://polsis.mk.gov.Iv/documents/3323. Access: 02.01.2019.

18. PKC (Parresoru koordinacijas centrs) (2012b). Latvijas Nacionalais attistibas plans 2014.-2020.gadam (NAP2020). Retrieved: https://www.pkc.gov.Iv/lv. Access: 06.01.2019.

19. Radinger-Peer, V., Pflitsch, G. (2017). The role of higher education institutions in regional transition paths towards sustainability. Review of Regional Research, Vol. 37(2), pp 161-187.

20. Sinkiene, J., Grumadaite, K. (2014). Sumanaus regioNo konceptualus modelis. Viešoji politika ir administravimas, Vol.13 (3), pp.414-426.

21. Trippl, M., Sinozic, T., Lawton-Smith, H. (2015). The role of universities in regional development: conceptual models and policy institutions in the UK, Sweden and Austria. European Planning Studies Vol.23 (9), pp.1722-1740.

22. Vīksne, D., Mazūre, G. (2007). Development of Human and Financial resources in RHEIs of Latvia. Economic and Rural Development, Vol 3 (2), Kaunas: Akadēmija, pp. 28-36. 